\title{
長寿命化トレンドを考慮した建物残存率のシミュレーション 建物の長寿命化トレンドにおける建材のストック/排出量の算出手法に関する研究その 1 SIMULATION OF BUILDING RESIDUAL RATIO UNDER THE TRENDS
IN LONGER LIFE OF BUILDINGS
}

Estimation method of stock/wastes of building materials under the trends in longer life of buildings Part 1

\author{
小見康夫*，栗田紀之**
}

\section{Yasuo OMI and Noriyuki KURITA}

\begin{abstract}
Residual ratio of buildings greatly influences the estimation of building stock and amount of wastes from building demolition. However, it may depend on not only the age of buildings but also the age in which buildings exist. Especially, social background in Japan is drastically changing and building stock became more important than ever so that lifetime of buildings seem to be extended. This study discusses an estimation method of residual ratio of buildings under the trends in longer life of buildings as follows,

1. The simulation in which the residual ratio of buildings changes corresponding to both the age of buildings and the age in which buildings exist.

2. Verification of residual ratio of buildings by comparing between new residential construction statistics and housing stock statistics from 1961 to 1990.
\end{abstract}

Keywords : Life time, Building residual ratio, Building Stock, Weibull distribution 而讨用期間，建物残存率，建築ストック，ワイブル分布

\section{1.はじめに}

筆者らは既報 ${ }^{1)}$ において、建物ストック中に現存する発泡系断熱 材の総ストック量と、それらの材齢別内訳を推計した。これは、建 物の新築及び滅失により刻々と変化する建物ストックと、そこに使 用された断熱材を追跡したもので、推計のベースとなったのは(1)建 築着工統計と (2)建物種別滅失率（確率密度関数）である。このうち (1)は国土交通省により毎月調查・公開されるが、(2)はそもそも調査 が行われていない注 1 。人間で言えば、出生数のデータはあるものの、 年齢別死亡率や平均寿命（平均余命）に該当する公的データが存在 しないことを意味している。そこで、加藤らによる研究 ${ }^{2)}$ で示され た滅失率を引用した。これは、1987 年時の固定資産税台帳のデータ をもとに、建物の累積滅失率を関数で近似したもので、建物種別の 一揃いのデータとしては当時ほぼ唯一のものであった。

続く既報 ${ }^{3)}$ では、この滅失率を用いて木造住宅のストックを時系 列で変化させ、その差分から主要建材の今後の排出量を予測した。

以上の研究は、いずれも「建物の滅失率は、建物種類とその経年 により決定される」ことを前提とするものであった。ただし、これ には「同じ建物種類、経年の建物でも、その滅失率は時代によって 変化するのではないか」との疑問が残る。すなわち、建物を長持ち させる技術の進歩や価值観の変化により、滅失率が時代にも依存す
るのではないかという疑問である。特に、人口増から人口減へと社 会が転換し、建物もフローからストックへとその重心を移行する中、 リフォーム（修繕やリノベーション、コンバージョン等）が一般化 し、建物寿命も昨今少なからず伸展していることは想像に難くない。 少なくとも今後の建物滅失が影響する種々の推計において、滅失率 が時代で変化しないとの前提にやや無理があることは否めない。

本報告は、建物の長寿命化トレンドにおいて、その滅失率をどう 扱うべきかについて考察するものであり、既存の観察データを用い た統計的処理により、建物残存率が時代と共に変化するシミュレー ションを行う。さらにその結果を用いて、(建築着工統計による) 着 工新設住宅数をもとに住宅ストック量を推計し、(住宅・土地統計調 査による）建築の時期別住宅数と比較することで、長寿命化トレン ドを考慮した推計方法の有効性について検証する。これら一連の考 察により、従来に比べて精度の高い将来予測が可能になる。

高度成長期以降に建設された建物の多くが建替時期を迎える中、 一方で建物の長寿命化も進み、今後の建物の滅失時期やそれに伴う 建築廃材の排出量の予測は難しい状況にある。ストック量や排出量 はリサイクル施設や最終処分場などの計画、ひいては政策にも影響 を与える重要な要因であり、本研究は、それらの基礎となる建物滅 失量の推計方法についての提案を行うものである。
* 東京都市大学工学部建築学科 准教授 $\cdot$ 博士 (工学)

** A/E WORKS 代表理事・博士(工学)
Assoc. Prof., Dept. of Architecture, Faculty of Engineering, Tokyo City University, Dr. Eng. Representative Director, A/E WORKS Association, Dr. Eng. 


\section{2. 建物の長寿命化トレンドにおける滅失率の変化}

建物の経年別の滅失率は、次のように同定することができる。す なわち、ある期間（ここでは $\mathrm{A}$ 年の一年間）に観察された既存建物 の滅失率を縦軸、その竣工年を横軸にとり分布をみると、例えば図 1 のようなグラフになる。これを縦軸で折り返してできるグラフ(図 2 ）を、経年別の滅失率の確率密度（故障密度）と見なす。すなわ ち $\mathrm{A}-x$ 年竣工の建物の $\mathrm{A}$ 年における滅失率を、経年 $x$ の建物の滅失 率と見な寸（実際には観察值を故障密度関数に近似して利用）。

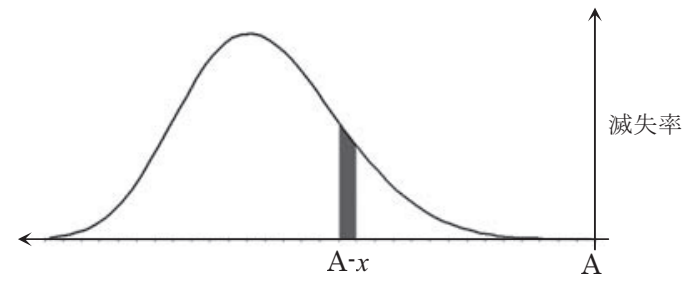

竣工年

図 $1 \mathrm{~A}$ 年に観測された竣工年別滅失率の分布

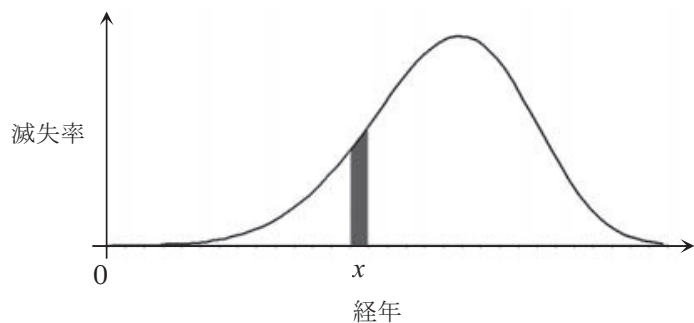

図 2 経年別滅失率（故障密度）の分布

もし建物の長寿命化が進んだ B 年において同様の観察を行うと、 グラフの形は例えば図 3 のように変化する。従って、経年別滅失率 のグラフも図 4 のように変化し、経年 $x$ の滅失率は $\mathrm{A}$ 年の観察值を 基にした場合とは異なる值をとることになる注2)。

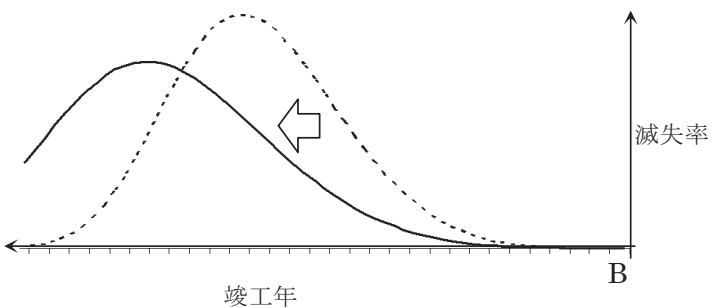

図 $3 \quad \mathrm{~B}$ 年に観測された竣工年別滅失率の分布

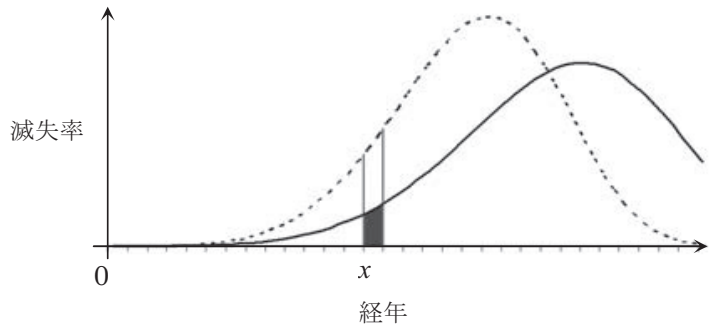

図 4 長寿命化による滅失率の変化

実際には、建物の滅失率はこのように急激に変化するのではなく、 徐々に変化（長寿命化）すると考えられる。ただし既述のように、 建物の竣工年別滅失についての公的な観察データが存在しないため、 それらを年々追跡することはできない。
3. $1987 \cdot 1997 \cdot 2005$ 年のデータによるシミュレーション そこで、既報でも用いた 1987 年データの分析結果と、それに続 く 1997 年、2005 年の (固定資産台帳による) 観察データ ${ }^{4)}$ 用い、 各年の故障密度関数を近似する方法について検討した。

まず、 3 つの時期の建物滅失率のデータを用い、時期による変遷 を同種のパラメータの変化で同定できるよう、それぞれ同種の故障 密度関数に近似する。ここでは位置パラメータ $\delta=0$ とするワイブル 確率密度関数を採用することとする注 3 )。

すなわち、ワイブル確率密度関数

$$
f(t)=\frac{m}{\eta^{m}} t^{m-1} \cdot \exp \left\{-\left(\frac{t-\delta}{\eta}\right)^{m}\right\}
$$

において $\delta=0$ 、すなわち

$$
f(t)=\frac{m}{\eta^{m}} t^{m-1} \cdot \exp \left\{-\left(\frac{t}{\eta}\right)^{m}\right\}
$$

で近似する。なお、各パラメータは以下の通り。

$t \quad:$ 時間パラメータ (ここでは築年数)

$m$ : 形状パラメータ $(\mathrm{m}>1$ の場合に摩耗型故障の形状となる $)$

$\eta \quad$ : 尺度パラメータ (グラフのスケーリングを決定)

また、この場合のワイブル累積分布関数（累積滅失率を示す）は、

$$
F(t)=1-\exp \left\{-\left(\frac{t}{\eta}\right)^{m}\right\}
$$

で表される。従って残存率関数は以下の通りとなる。

$$
R(t)=1-F(t)=\exp \left\{-\left(\frac{t}{\eta}\right)^{m}\right\}
$$

さて、1987 年のデータを用いた報告（既出 $\left.{ }^{2)}\right)$ では、建物種類別 の滅失率の観察值は掲載されていないが、それらをもとに故障密度 関数を対数正規分布またはワイブル分布で近似している。表 1 に各 パラメータを示す注4)。従って、まずこれらを $\delta=0$ のワイブル累積分 布関数で再度回帰させた注 ${ }^{5)}$ 。鉄骨造共同住宅は $\delta=0$ のワイブル分布 なのでそのまま採用した。他の 4 つはこれらのパラメータをもとに 累積分布関数を生成した後、 $\delta=0$ とするワイブル累積分布関数を用 い、 $m$ と $\eta$ を変化させて最小二乗法により再度回帰させた。

表 1 建物種類別の故障密度関数とパラメータ值（1987 年）

\begin{tabular}{|c|c|c|c|c|c|c|}
\hline 建物種類 & 分布形 & $m$ & $\eta$ & $\delta$ & $\mu$ & $\sigma$ \\
\hline $\mathrm{RC}$ 造共同住宅 & ワイブル分布 & 2.747338 & 61.51844 & -1.240550 & - & - \\
\hline $\mathrm{RC}$ 造事務所 & 対数正規分布 & - & - & - & 3.656244 & 0.5834942 \\
\hline 鉄骨造共同住宅 & ワイブル分布 & 3.005484 & 36.27570 & 0 & - & - \\
\hline 鉄骨造事務所 & ワイブル分布 & 2.367776 & 36.14284 & -1.672501 & - & - \\
\hline 木造専用住宅 & 対数正规分布 & - & - & - & 3.662955 & 0.635887 \\
\hline
\end{tabular}

次に、1997 年及び 2005 年のデータを用いた報告では、建物種類 別の滅失率の観察值が示されている。これを直接ワイブル確率密度 関数に近似回帰寸る手法も考えられるが、経年が大きくなると建物 現存棟数（サンプル数）が僅少になるため、滅失率に特異值が目立 つようになる。そこで、(1-滅失率) の值を築年数にしたがって積 み上げて建物残存率に換算した值を用い、1987 年データと同じ方法 でワイブル累積分布関数に回帰した。 
以上により得られた 1987 年、1997 年、2005 年におけるワイブ ル累積分布関数の $m$ と $\eta$ の結果を表 2 に、残存率関数 $(=1$ - 累積 分布関数）による近似の状況を図 5 〜図 9 に示す（残存率 1.0 は 100\%残存の意)。これらのグラフからは、同じ築年数でも、建物の 残存率が概ね時代と共に大きくなっている状況が読み取れる。

表 2 建物種類別・年代別のワイブル累積分布関数の同定

\begin{tabular}{|c|c|c|c|c|}
\hline 建物種類 & パラメータ & 1987 年 & 1997 年 & 2005 年 \\
\hline \multirow{2}{*}{ RC 造共同住宅 } & $m$ & 2.6507 & 4.6818 & 5.2185 \\
\cline { 2 - 5 } & $\eta$ & 60.498 & 46.955 & 49.259 \\
\hline \multirow{2}{*}{$\mathrm{RC}$ 造事務所 } & $m$ & 2.2512 & 2.9669 & 2.9284 \\
\cline { 2 - 5 } & $\eta$ & 46.184 & 52.855 & 56.908 \\
\hline \multirow{2}{*}{ 鉄骨造共同住宅 } & $m$ & 3.0055 & 2.9924 & 4.5208 \\
\cline { 2 - 5 } & $\eta$ & 36.267 & 45.777 & 50.543 \\
\hline \multirow{2}{*}{ 鉄骨造事務所 } & $m$ & 2.2280 & 2.0652 & 2.1593 \\
\cline { 2 - 5 } & $\eta$ & 34.413 & 38.710 & 48.639 \\
\hline \multirow{2}{*}{ 木造専用住宅 } & $m$ & 2.0780 & 2.6192 & 2.9624 \\
\cline { 2 - 5 } & $\eta$ & 47.048 & 51.683 & 62.498 \\
\hline
\end{tabular}

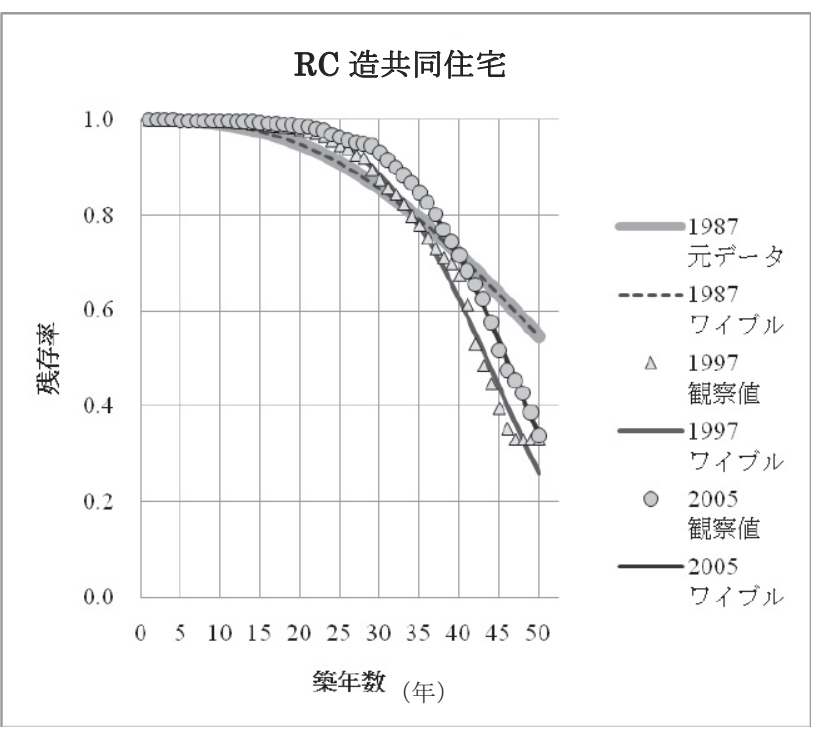

図 $5 \mathrm{RC}$ 造共同住宅の残存率における近似の状況

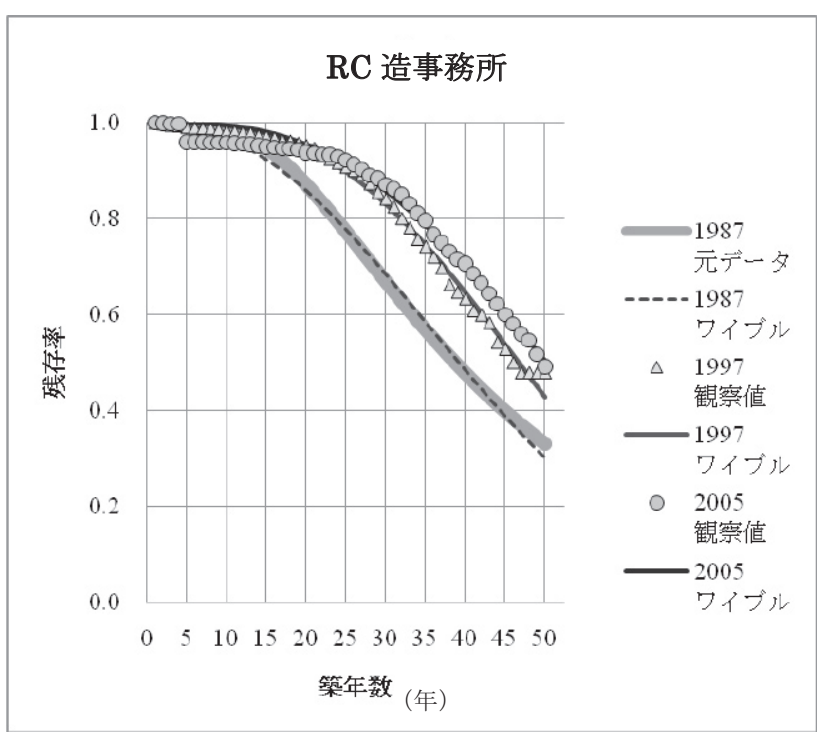

図6 $\mathrm{RC}$ 造事務所の残存率における近似の状況

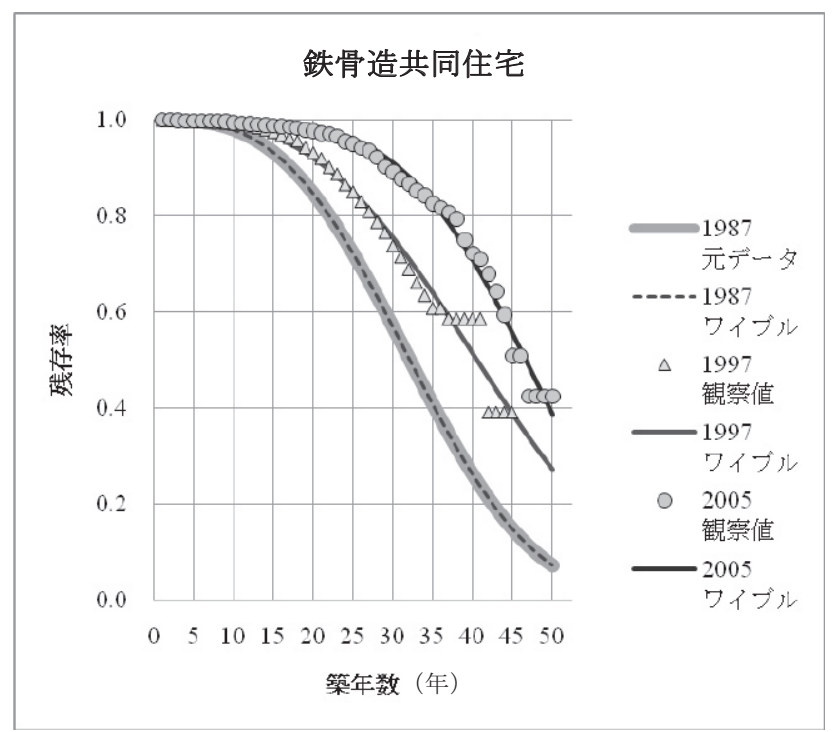

図 7 鉄骨造共同住宅の残存率における近似の状況

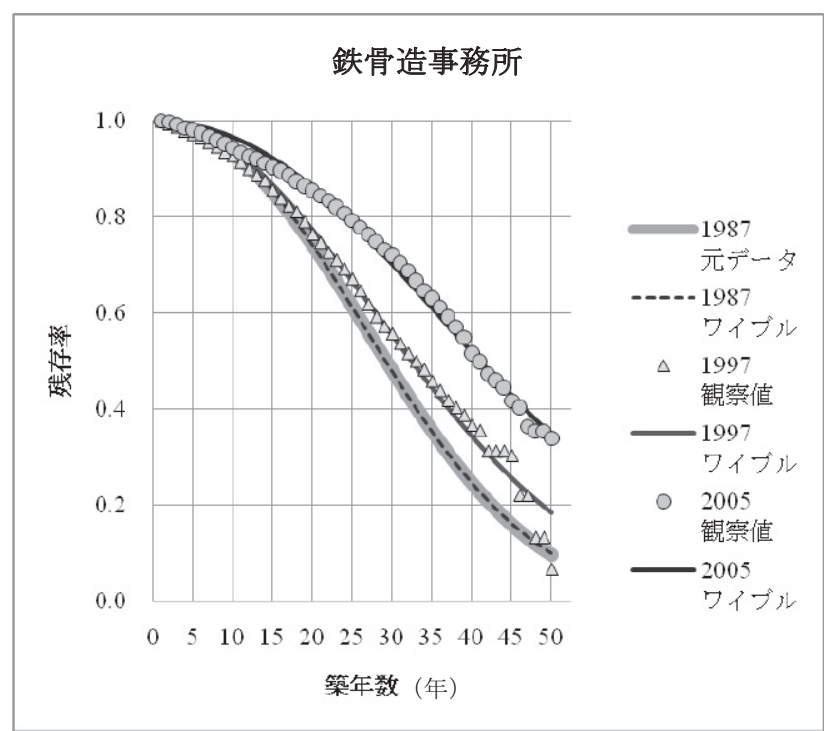

図 8 鉄骨造事務所の残存率における近似の状況

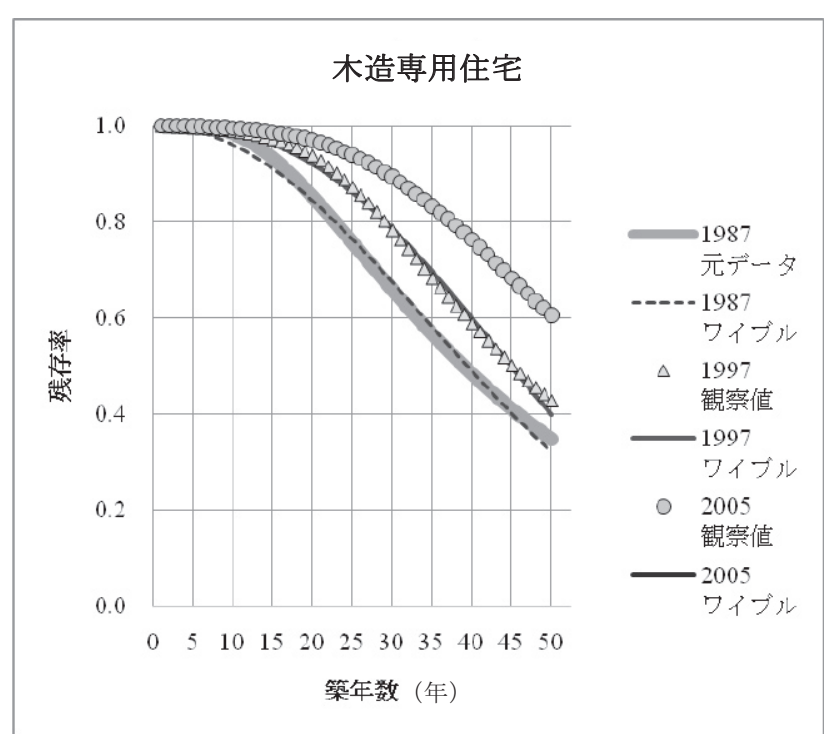

図 9 木造造専用住宅の残存率における近似の状況 
そこで、これら 3 つの年の $m$ と $\eta$ を年次に応じて線形で補間また は（前方に）外挿することで注 6 ，他の年のワイブル確率密度関数及 びワイブル累積分布関数を同定した。「y年における築年数 $t$ 年の建 物は、 $y$ 年のワイブル確率密度関数 $f_{y}(t)$ にしだって滅失する」とみ なせば、建物の長寿命化トレンドを反映した推計が可能になる。こ れらの $m$ と $\eta$ を用い、建物種類別に残存率関数 $1-F_{y}(t)$ でシミュレ ーションを行った結果が図10〜図14 である。

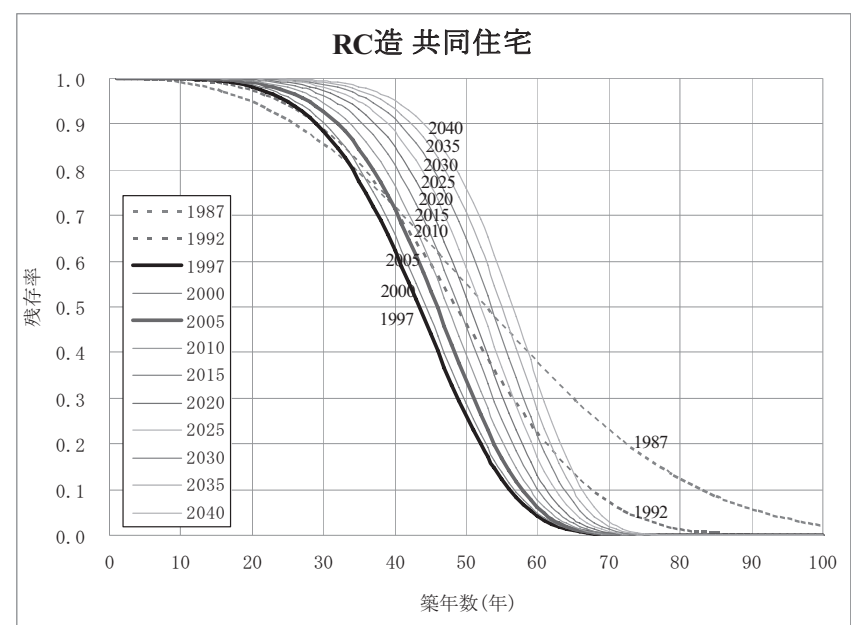

図 $10 \quad$ R C 造共同住宅の残存率関数のシミュレーション

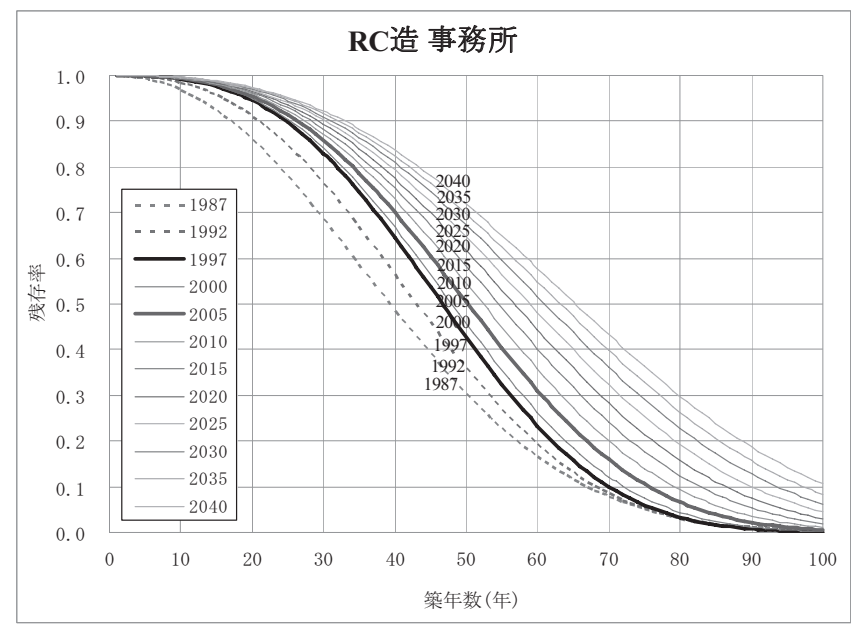

図 11 R C 造事務所の残存率関数のシミュレーション

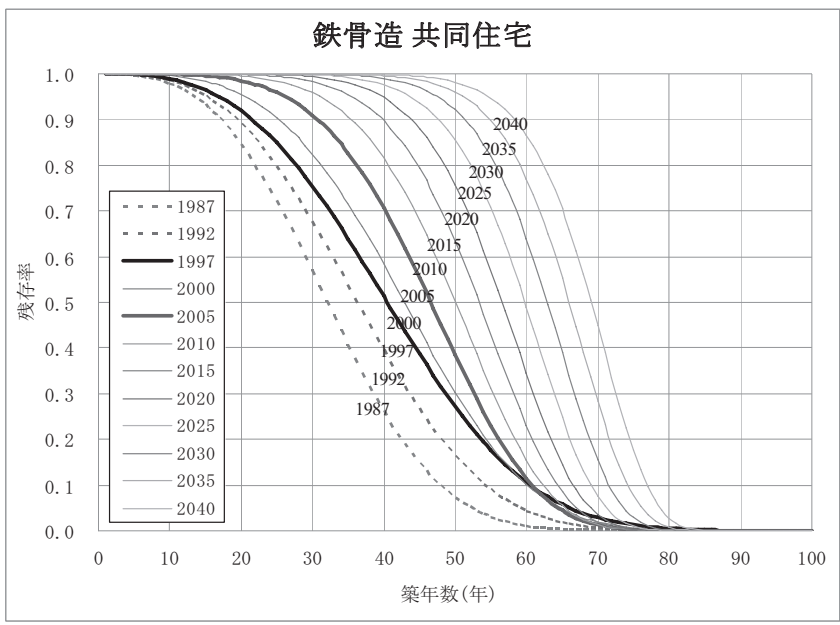

図 12 鉄骨造共同住宅の残存率関数のシミュレーション

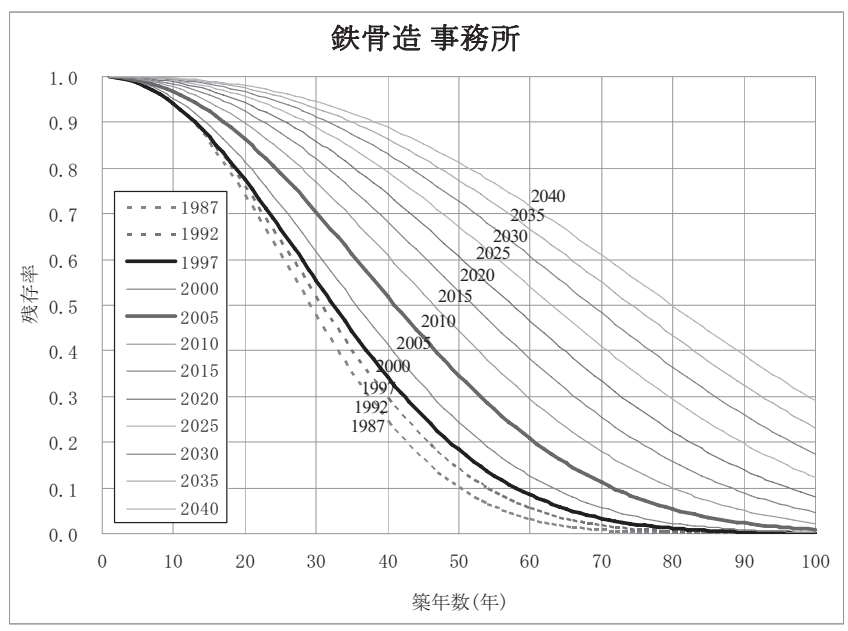

図 13 鉄骨造事務所の残存率関数のシミュレーション

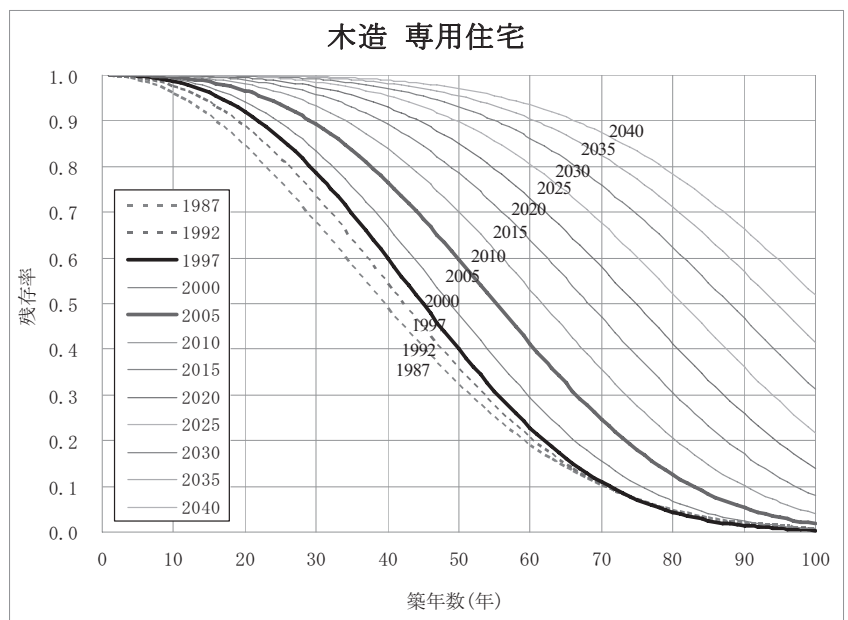

図 14 木造専用住宅の残存率関数のシミュレーション

これらのシミュレーションでは、RC 造共同住宅の 1987〜 1997 年の期間注 7) を除き、残存率が時代と共にほぼ全ての築年数で上昇す る結果が導かれた。いま、建物寿命を残存率が 0.5 に至るまでの年 数注 8$)$ とすると、各年におけるとれらの值は図 15 に示寸通りとなる。 $\mathrm{RC}$ 造共同住宅が 1987〜 1997 年で減少すること、2010 年以降の 推測值では、木造専用住宅の伸びが他に比べてやや大きい注9)ことを 除けば、全体としては長寿命化のトレンドを適度に反映したシミュ レーション結果と考えられる。

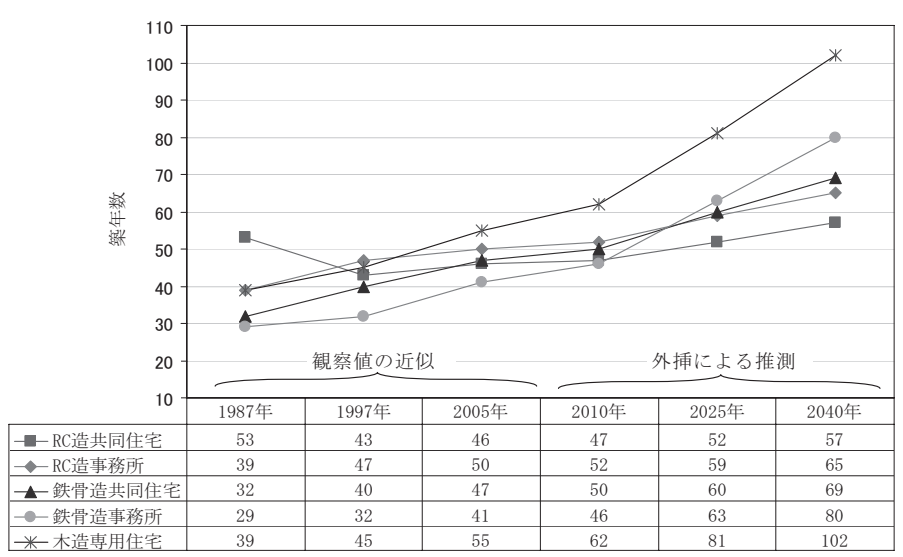

図 15 残存率が 0.5 に達するまでの年数の変化 


\section{4 . 住宅ストック量の推計による有効性の検証}

そこで、これらの結果を用いて、過去に建設された住宅の残存数 を推計し、実測データと比較してその有効性を検証した。信頼でき る公的データとして、毎年の住宅の建設量（住宅フロー）には国土 交通省が行う建築着工統計調查の着工新設住宅数 ${ }^{5)}$ を、住宅の残存 量（住宅ストック）には総務省が 5 年ごとに行う住宅・土地統計調 查の住宅総数を用いた注 ${ }^{10)}$

住宅・土地統計調查には、10 年間の区分で集計される「建築の時 期別住宅数」の公表データがある。そこで、対象を 1961 年から 1990 年に着工された新設住宅に絞り注 ${ }^{11)}$ 、次の方法で推計值と比較した。

(1)1961〜1990 年の各年の新設住宅を、RC 造共同住宅、鉄骨造共 同住宅、木造専用住宅のグループに分け注 ${ }^{12)}$ 、それぞれ既述の シミュレーションで用いた時代別・建物種類別のワイブル確率
密度関数 $f_{y}(t)$ に従って毎年漸減させる (表 3 に例を示す) ${ }^{\text {注 }}{ }^{13)}$ これを「ワイブル補間・外挿による推計」と呼ぶことにする。 このとき比較対象として、1987 年及び 2005 年のワイブル確率 密度関数 $f_{1987}(t) 、 f_{2005}(t)$ に固定して漸減させたものもそれぞれ用 意する（これらは「ワイブル 1987 年固定による推計」「ワイブ ル 2005 年固定による推計」と呼ぶことにする)。

(2)こうして推計された各年の新設住宅の残存数を、10 年ごと（着 工年が 1961〜1970 年のもの、1971〜1980 年のもの、1981〜 1990 年のもの) でまとめ、1998 年、2003 年、2008 年におけ る残存数を推計する (表 4 )。

(3)これらの推計值を、1998 年、2003 年、2008 年の住宅・土地統 計調查による（建築の時期別の）住宅総数、及びこれらの補正 值注 14) と比較する（図 $16 \sim 18$ ）。

表 3 着工時期別新設住宅の残存数の推移の一例 (1961〜1970 年着工分/木造専用住宅/ワイブル補間・外挿による推計) (※表中の太枠で囲んだ斜体文字は表 4 のそれらに対応)

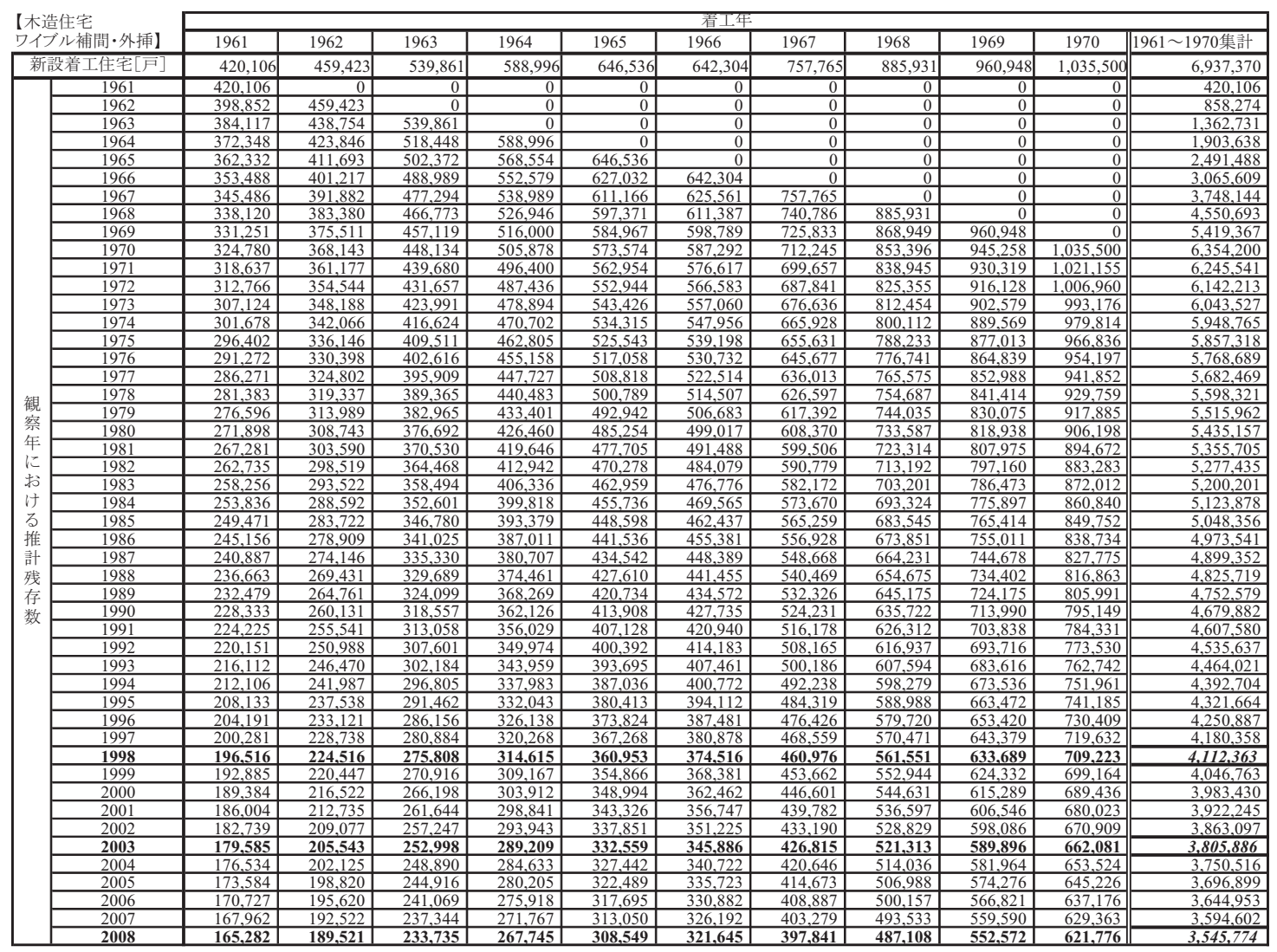

表 4 着工時期別新設住宅の残存数の推計結果

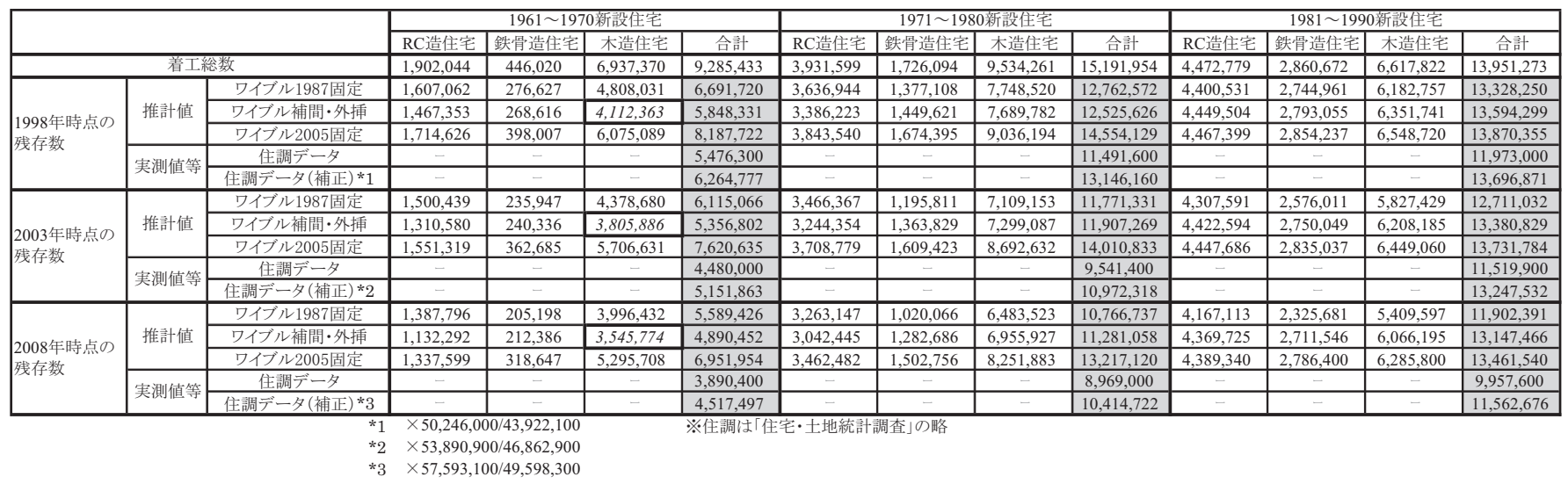


図1 6 〜 18 をみると、「ワイブル補間・外挿による推計」の結 果は、どの時期に建てられた住宅に対しても、実際のストック数と 見なすことのできる「住宅・土地統計調查の補正值」に近い值で推 移している注 ${ }^{15)}$ 。特に経年数が大きい 1961〜1970 年の新設住宅で は、「ワイブル 1987 年固定による推計」や「ワイブル 2005 年固定 による推計」の結果が実際とは大きく乘離してしまう（約 100 万〜 200 万戸もの差が生じている）のに対して、依然として高い精度を 保っており、推計方法として有効であると考えられる。

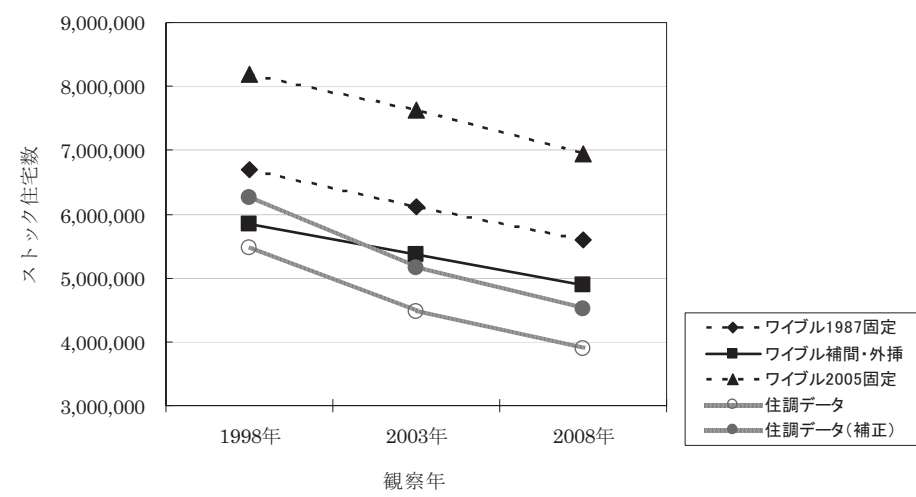

図 16 1961 70 年の新設住宅における推計值・実測值等の推移

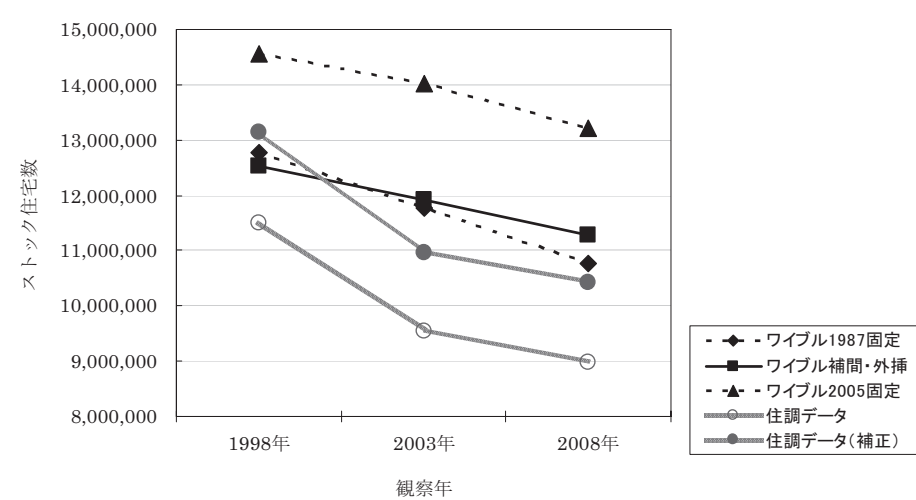

図 17 1971 80 年の新設住宅における推計值・実測值等の推移

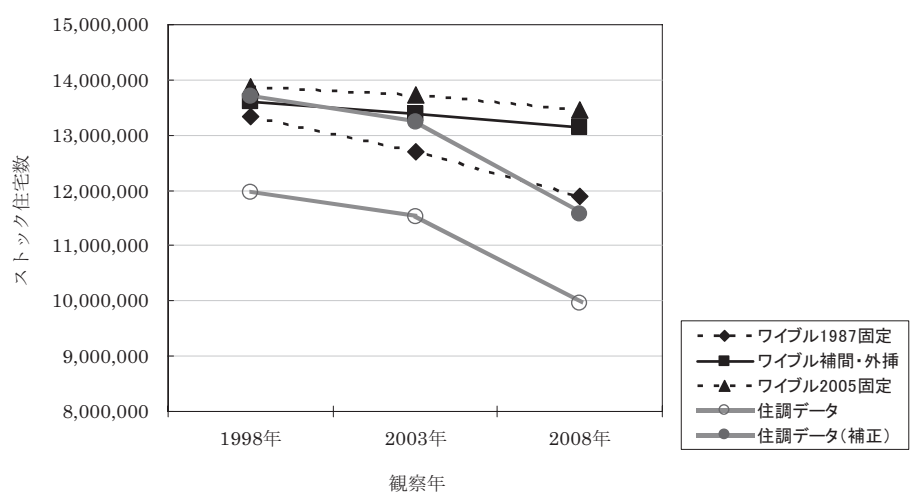

図 18 1981 90 年の新設住宅における推計值・実測值等の推移

\section{5. 結論}

本報告では、既存の建物滅失データをもとに、近似したワイブル 関数を補間・外捙により年次に応じて順次変化させることで、長寿 命化トレンドを反映した建物の滅失率の同定方法についての提案と その検証を行った。

限られた年次・期間の観察データを用い、パラメータの漸進的変 化の仮定をもとに推計を行っているため、統計上の有意水準が保証 されるものではないが、住宅のフロー、ストックそれぞれの全国統 計データを用いた検証では、推計值と実際の值がよく一致すること が示された。また、長寿命化トレンドを考慮しない従来の推計方法 では、経年数が大きくなるにつれて両者の差がかなり大きくなるこ とも明らかになった。

以上から、(1)従来の方法で算出されてきた種々のストック推計手 法には見直しの検討の余地があること、(2)本研究で提案する「ワイ ブル補間・外挿による推計」を用いたストック推計手法は、従来に 比べて精度の高い結果を導き得る手法として、一定程度の信頼性・ 実用性を有寸ると判断できること、などが明らかになった。ただし、 提案手法においても、推計精度をより高くするには、同定するパラ メータの精度を高める必要がある。それには建物残存率の観察デー タを増やし、推計にフィードバックさせていくことが望ましい。

将来の建物のストック量や滅失量の推計手法が異なれば、それに 伴う建築廃材の排出量の推計結果も修正が必要となる可能性がある。 次報では、石膏ボード及びアスベスト含有建材の事例をもとに、そ れらの排出量の推計について検討を行う予定である。

\section{参考文献}

1）小見康夫・野城智也·佐藤考一・栗田紀之：建築用硬質ポリウレタンフォー ム断熱材のストック量の推計一既存建物における使用建材の総ストック 量及び発生廃材量に関する研究(その 1 ), 日本建築学会環境系論文集 第 578 号, pp. 97-101, 2004.4

2）加藤裕久·吉田倬郎・小松幸夫 ・ 野城智也 : 住宅の寿命分布に関する調査 研究(2), 住宅総合研究財団研究年報 NO.18, pp357-366、1991

3）小見康夫 : 木造住宅の滅失による廃材料の推計及びその再利用・再資源化 に関する考察一既存建物における使用建材の総ストック量及び発生廃材 量に関する研究（その 2)，日本建築学会環境系論文集 第 584 号, pp107-112，2004.10

4）小松幸夫 : 1997 年と 2005 年における家屋の寿命推計, 日本建築学会計画 系論文集 第 632 号，pp2197-2205，2008.10

5）建築統計年報（平成 21 年度版），財団法人建築物価調査会， 2010.1

注

注 1）国土交通省では建築着工統計調査と同時に建築物滅失統計調査を行い、 除却や災害により失われた建築物の数及び床面積の合計を公表してい るが、それらがいつ着工されたものかについての情報がないため、建 物の滅失率は不明である。

注 2) 故障密度がじのような分布になるかは、扱う対象や故障の種類 (初期故障、 偶発故障、摩耗故障)によって異なる。ここでは建物の耐用寿命による滅失 が主たる対象であり、摩耗故障を想定した議論を行う。信頼性工学の分野 では、摩耗故障の確率分布は正規分布・対数正規分布・ワイブル分布 (後 述するように形状パラメータ $m>1$ の場合)などに比較的よく適合することが 知られているが、いずれにしても上に凸の釣鐘形 (左右対称とは限らない)と なり、耐用寿命が長くなればその山は変形しながら時間軸の正の方向にず れると考えられる。図 1〜4はそれらを定性的に表したものである。

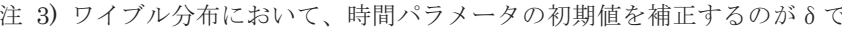
ある。ここでは相互のワイブル確率密度関数を比較し、形状パラメー タ（m)・尺度パラメータ（ $\eta)$ でトレンドを回帰（補間・外挿）でき 
るよう、竣工後の経過年=経過時間、すなわち $\delta=0$ として単純化した。 これは建物の竣工とともに劣化が始まることを意味しているが、建物 滅失の意味から考えてこの仮定に特に問題はないと考えられる。

注 4) 対数正規分布のパラメータのうち、 $\mu$ は平均值、 $\sigma$ は標準偏差を示す。

注 5）表 1 で示寸ように、故障密度関数としてワイブル分布以外に対数正規 分布が用いられているが、故障率が時間 $t$ の対数 $\ln (t)$ で正規分布する 対数正規分布は、故障自体は偶発的だが一定以上時間が経過するとそ の確率が極めて緩慢に減衰する現象に適しているのに対して、ワイブ 儿関数は故障率が比較的早い段階で収束する (一定以上時間が経過す ると概ねどのサンプルも故障に達する) 摩耗的現象に多く適用される。 観察值による一定区間の分布形状の近似よりも建物滅失の意味を優先 し、その分布を外挿して将来予測に用いるなら、ワイブル分布で再度 回帰することにも一定の妥当性があると考えられる。

注 6)一般に劣化現象や故障（ここでは滅失）のメカニズムやストレスが変 化すると、ワイブル分布のパラメータ $m$ および $\eta$ が変化する。 $m$ があ

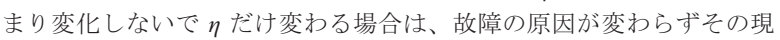
象の発生速度が変化したと考えられ、 $m$ が変化する場合は故障の原因 も変化したと考えられる。建物の滅失には機械の故障のような物理的 要因だけでなく、性能・機能の陳腐化や経济情勢、所有者の状況や㖺 好など様々な要因が関連するため、長寿命化にあたっては $m$ と $\eta$ の双 方が変化すると考えるのが適当である。ただし 1987 年、1997 年、 2005 年で同定した $m \cdot \eta$ の值の補間・外挿から他の年のそれらを求めても、 通常の有意水準で統計的有意性を確認することは難しい。ここではマ クロでみた建物の長寿命化は漸進的に進むとの認識から「隣接する年 次においてパラメータは漸進的に変化する」との仮定をもとに補間・ 外挿を行い、その結果を採用した。これらから提案される推計手法の 信頼性・実用性は、後述する実データを基にした検証により確認して いる。

注 7） 1987 年時点における RC 造共同住宅は、区分所有法により民間マンシ ヨンの供給が本格的に始まった 1962 年から数えても最大 25 年が経過 しているに過ぎない。従って経年劣化による滅失だけでなく、その他 の偶発的な理由による滅失が相対的に多く、結果として緩やかな残存 率曲線を描くことになったと考えられる。一方、1987 年はいわゆるバ ブル経済が始まった年とされており、その直後からマンションの新 築・建て替えが活発化するとともに、築 30 年を超える建物が徐々に増 加して滅失に至ったため、1997 年や 2005 年では大きく様相の異なる 曲線を描き、最終的には 5 つの建物種の中でも最も短寿命な性状を示 すことになった。これらは RC 造共同住宅の特殊な状況を反映したも のと考えられる。

注 8）これは半減期を平均寿命とみな寸もので、注 3）や注 5）でも同様の方 法で検討を行っている。ちなみにワイブル分布自体の平均值 $\mu$ は次の ガンマ関数で与えらる。

$$
\mu=\eta \times \Gamma\left(1+\frac{1}{m}\right)
$$

これを用いた計算結果は次の表のようになる。こちらを平均寿命とみ なすこともできるが、各々の值は半減期の場合とほとんど変わらず、 大勢には影響ない (両者の差は最大でも約 2 年)

\begin{tabular}{|r|c|c|c|c|c|c|}
\hline & 1987 & 1997 & 2005 & 2010 & 2025 & 2040 \\
\hline $\mathrm{RC}$ 造共同住宅 & 53.8 年 & 42.9 年 & 45.3 年 & 46.8 年 & 51.3 年 & 55.7 年 \\
\hline $\mathrm{RC}$ 造事務所 & 40.9 年 & 47.2 年 & 50.8 年 & 53.0 年 & 59.7 年 & 66.4 年 \\
\hline 鉄骨造共同住宅 & 32.4 年 & 40.9 年 & 46.1 年 & 49.4 年 & 58.9 年 & 68.2 年 \\
\hline 鉄骨造事務所 & 30.5 年 & 34.3 年 & 43.1 年 & 48.6 年 & 65.1 年 & 81.8 年 \\
\hline 木造専用住宅 & 41.7 年 & 45.9 年 & 55.8 年 & 62.0 年 & 80.9 年 & 100.2 年 \\
\hline
\end{tabular}

注 9) 30 年後の 2040 年に新築される木造専用住宅が築 102 年、すなわち 2142 年において半数残存しているという予測は、100 年超の住宅を目 指寸長期優良住宅の関連政策が現在活発に進められていることから考 えると、全く意外ではないが、他の建物種類の值と比べると、ややバ ランスを欠く結果になっている。

注 10）住宅・土地統計調查は 5 年毎の $9 \sim 10$ 月に実施される。直近では 2008 年に調查が行われ、2010年 2 月に確定版の集計結果が公表されている。 一方、住宅の着工統計は毎月の調査結果の集計データ（ここでは 1〜 12 月の年次で集計したもの）を用いており、建築期間や調查時期を考 えると両者の時期の扱いには若干の時差があるが、ここでは無視する こととした。
注 11）住宅・土地統計調査の時期別住宅数では 1951〜1960 年のデータも女 るが、その時期は着工数が 20〜 40 万戸/年程度と少なく、また RC 造 や鉄骨造の住宅もほとんど無いため、比較対象の時期から外した。 1991〜2000 年（及びそれ以降）のデータについては、一部が 1998 年 の観察年を超える上、築年数が浅いと偶発故障型の滅失が支配的にな り、ここでの議論にそぐわない等の理由から、対象時期から外した。

注 12）住宅着工統計では、「木造」「鉄骨鉄筋コンクリート造」「鉄筋コンクリート造」 「鉄骨造」「コンクリートブロック造」「その他」の6つの構造別のデータがある。 ここでは、木造う木造専用住宅、鉄骨鉄筋コンクリート造十鉄筋コンクリート 造十コンクリートブロック造 $\fallingdotseq \mathrm{RC}$ 造共同住宅、鉄骨造十その他う鉄骨造共 同住宅に分け、それぞれの滅失率関数に従うとみなした。

注 13）図10〜図14には示されていないが、1986 年以前についても(後方に)外 挿を行い、毎年の滅失率関数を同定したものを計算に用いた。

注 14）住宅・土地統計調査における建築の時期別データは、近年増加の一途 を辿っている「空き家等」を含んでいない。そこで、各データに （空き家等を含む総住宅数／空き家等を含まない総住宅数） を乗じた值をそれぞれの補正值とした。

注 15）1981 1990 新設住宅では、「ワイブル補間・外挿による推計」よりも「ワイブ ル 1987 年固定による推計」の方がよく一致している(特に 2008 年)。これは、 そもそも建物滅失率の観察年である 1987 年が 1981〜 1990 年の間にある からだが、比較的短いスパンなら (2008 年時の経年は 18〜27 年)、時代と ともに滅失率を変化させるのが必ずしも有効に働かない可能性があることを 示唆している。その説明として、比較的初期の滅失は、時代の影響よりも初 期性能や偶発的理由が支配的であることが考えられる。ただし、滅失の観 察值がない時代につくられた住宅の滅失関数は、補間や外挿によって同定 寸るしかなく、また、経年が十分大きくなると時代の影響が大きくなってくるこ とは分析からも明らかであり、全体として補間・外挿による推計方法の優位 性を損䣓るものではないと判断される。

（2010年 2 月 28 日原稿受理，2010年 7 月 1 日採用決定） 